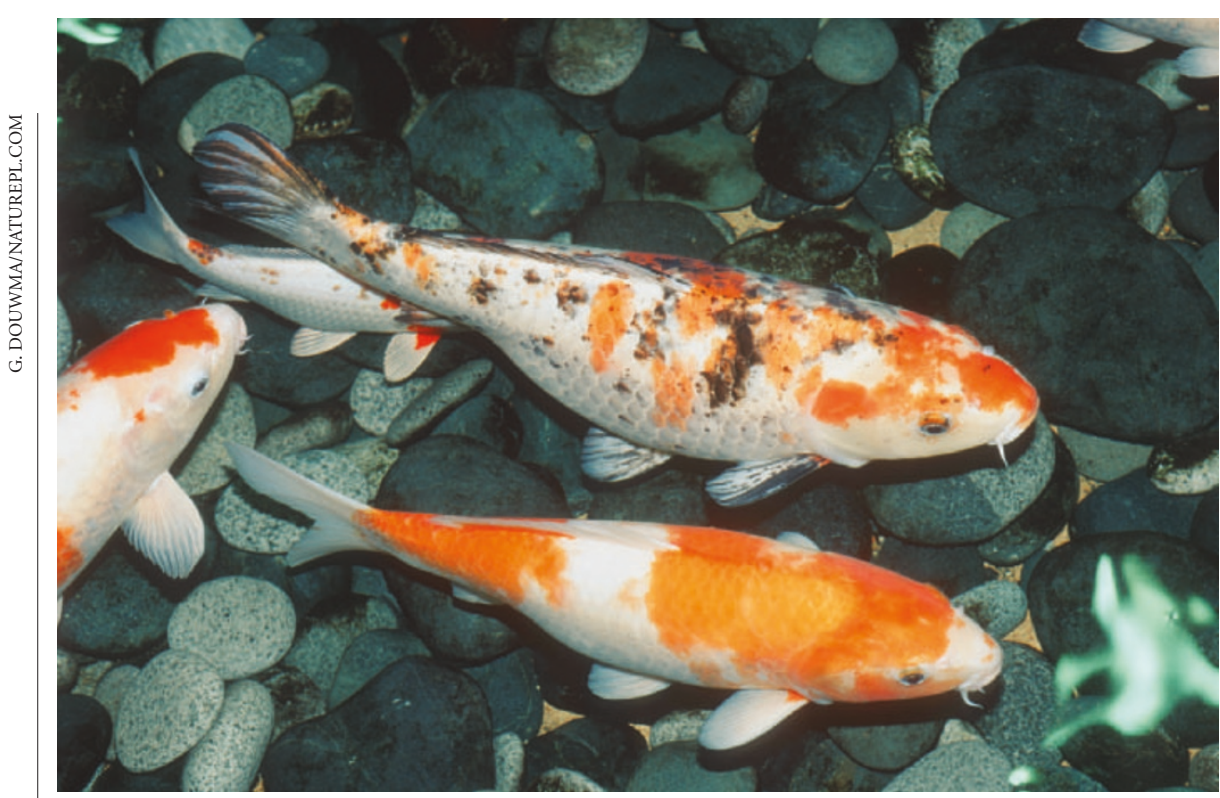

Aquatic peril: common carp, one of the top fishing stocks in the Far East, face a threat from herpes.

\title{
Carp virus crisis prompts moves to avert global spread
}

\section{Helen Pearson}

Fish disease experts are meeting in London this week to figure out how to contain a viral disease that is razing populations of carp.

Fish populations are periodically struck with viral diseases, but koi herpes virus, or $\mathrm{KHV}$, is killing four out of every five fish that it infects, and has spread rapidly around the world. "In the past 30 years it's the worst and most rapidly spreading virus I've dealt with," says Ron Hedrick, who studies infectious diseases in fish at the University of California, Davis.

The disease threatens two important fish populations: the ornamental koi carp industry, which is worth tens of millions of dollars in Japan, and the common carp, the world's fourth most-farmed fish.

The herpes virus was first isolated in Israel in 1998, and has since been detected in ornamental koi carp in Europe, Asia and the United States. Last year it started killing large numbers of common carp in Japan. Authorities there were alerted to the problem in October, when fish began dying in Ibaraki prefecture's Lake Kasumigaura, where more than half of Japan's farmed carp are produced.

By the end of 2003, the disease had been reported in common or koi carp in 23 of Japan's 47 prefectures, according to Motohiko Sano of the National Research Institute of Aquaculture in Tamaki.

Experts fear that the virus could cause further economic damage if it spreads to farmed carp stocks in other countries - particularly in China, which produces three-quarters of the world's farmed carp. "We could have a situation where it reaches the wild population and potentially decimates it," says Hedrick.

The London meeting, to be held on 12 and
13 February, will bring together researchers, animal-health experts and representatives from the ornamental-fish industry.

One point for discussion will be the lack of an effective test for the virus, particularly one that can reliably detect it during its sometimes lengthy asymptomatic phase. "The industry is almost screaming for a detection method that will tell you where this virus is," says Keith Davenport, chief executive of Britain's Ornamental Aquatic Trade Association, based in Trowbridge.

Researchers attending the meeting say they also want to know where the new virus first emerged - whether it jumped into carp from another species, for example. This might help them to anticipate and prevent other new fish infections. "Finding out where these things are originating might change the way they are handled in the future," says Hedrick.

Another issue is whether international trade in ornamental fish, which is thought to have fuelled the spread of the virus, should be more tightly controlled. Although fish imported for aquaculture are subject to rigorous health inspections, regulations on the transport of ornamental fish are more hit and miss.

Some researchers say that the virus should be included in a list of certifiable diseases compiled by the World Organisation for Animal Health. Nations would then be obliged to notify the agency within 24 hours of the disease being detected.

But Davenport argues that good practice within the industry can limit the disease without the need for further formal regulations. "Industry has no wish to trade in fish with this virus present," he says.

\section{Kofi Annan backs call for science push in developing countries}

Declan Butler

Scientific academies worldwide are calling for the establishment of two funds to boost research efforts in poor countries.

The InterAcademy Council - a coalition of 90 academies, including the US National Academy of Sciences delivered the idea last week in a report to Kofi Annan, the secretary-general of the United Nations (UN).

The report, Inventing a Better Future: A Strategy for Building Worldwide Capacities in Science and Technology, slams governments for failing to get behind laboratories, institutions and policies in developing countries that could serve as powerful engines for their economic development.

It recommends that a Global Institutional Fund be set up to support 20 centres of national or regional excellence over periods of between five and ten years, selected on the basis of the quality of their science, independence, management calibre and relevance to the needs of their regions. A second Global Program Fund would operate a competitive grant system, with international referees assessing proposed joint projects between laboratories in rich and poor countries.

The funds would be supported by contributions from governments, foundations and existing international organizations, although the scale of their support is not specified.

Annan, who chaired a debate to discuss the recommendations at the UN headquarters in New York, welcomed the report and said he would work with its authors to implement their proposals.

He said his top priority was the application of science and technology in agriculture: "I challenge the scientific community to ask why Africa is the only continent not to have had a green revolution."

The 161-page report features an exhaustive list of initiatives that it says would boost science and innovation in poor countries. "A lot of what it says ought to have already happened, but it's got to be restated," says Peter Bruns, vice-president for grants and special programmes at the Maryland-based Howard Hughes Medical Institute. But he cautions that initiatives must be driven by existing research institutions, not by creating additional bureaucracies. 